\title{
"Never in my life have I heard such a load of absolute nonsense. Wtf." Political satire on the handling of the COVID-19 crisis
}

\author{
Douglas M. PONTON \\ University of Catania \\ Catania, Italy
}

\begin{abstract}
This paper problematises political satire in a time when the COVID-19 virus has provoked numerous deaths worldwide, and had dramatic effects on social behaviour, on a scale unknown in western nations since World War II. Most populations have endured 'lockdown', periods of enforced domestic imprisonment, which led to images of the empty streets of big cities appearing in media, symbols of the drastic changes that the health emergency was making necessary. Yet, from the outset, comic memes began to circulate across (social) media, while in mainstream print media political satirists continued to lampoon official responses to the ongoing crisis. The paper thus aims to explore the connection of political satire and humour, asking two principle research questions: firstly, how to explain the humorous effects of these multimodal artefacts in such depressing circumstances; secondly, from a pragmatic perspective, to account for their overall socio-political function. The study uses memes taken from various online sources (Facebook, Twitter, Google) during the crisis, analysed according to a mixed approach that blends notions from Humour studies, especially incongruity (Morreall 2016), with insights from linguistic pragmatics (e.g. Kecskes 2014). The findings emphasise the emotional dimension of this form of satire, as the memes work against the backdrop of a range of feelings (anger, bitterness, disappointment, frustration, despair, etc.), many of which have been widely generated by the COVID-19 crisis and political responses to it. In short, to paraphrase Walter Benjamin (2008: 378), man may 'run out of tears but not of laughter'. The findings contribute to our understanding of online satire as an emergent genre, one that uses the affordances of new media to extend the social potentialities of a traditional subversive discourse form.
\end{abstract}

Keywords: humour, political satire, COVID-19, satirical discourse, memes

For citation:

Ponton, Douglas M. 2021. "Never in my life have I heard such a load of absolute nonsense. Wtf." Political satire on the handling of the COVID-19 crisis. Russian Journal of Linguistics 25 (3). 767-788. https://doi.org/10.22363/2687-0088-2021-25-3-767-788 


\title{
«Никогда в жизни я не слышал столько абсолютной бессмыслицы»: политическая сатира как способ преодоления кризиса COVID-19
}

\author{
Дуглас Марк ПОНТОН \\ Катанийский университет \\ Катания, Италия
}

\begin{abstract}
Аннотация
В данной статье рассматривается жанр политической сатиры в период, когда по всему миру вирус COVID-19 унес жизни многих людей и оказал глубокое драматическое влияние на социальное поведение в обществе. Население многих стран пережило «самоизоляцию», периоды принудительного домашнего заключения. В средствах массовой коммуникации появились изображения пустых улиц больших городов, символы радикальных изменений, необходимых в связи с чрезвычайной ситуацией в области здравоохранения, и неизвестные в западных странах со времен Второй мировой войны. В этой ситуации в основных печатных СМИ политические сатирики продолжали высмеивать официальные ответы властей на затянувшийся кризис, а в социальных СМИ начали появляться комические мемы. Цель данной статьи - рассмотреть связь политической сатиры и юмора, попытаться объяснить юмористический эффект этих мультимодальных артефактов в таких удручающих обстоятельствах и с прагматической точки зрения определить их социально-политическую функцию. В исследовании используются мемы, взятые из различных онлайн-источников (Facebook, Twitter, Google) в период пандемии, которые были проанализированы с применением комплексной методологии, с использованием понятий из исследований юмора, особенно понятия несовместимости (Morreall 2016), и основных положений лингвистической прагматики (Kecskes 2014). Результаты подчеркивают эмоциональную сторону этой формы сатиры и показывают, что мемы работают на основе ряда чувств (гнев, горечь, разочарование, отчаяние и т. д.), многие из которых были вызваны кризисом COVID-19 и политическими ответами на него. Перефразируя Уолтера Бенджамина (2008: 378), можно заключить: у человека могут «кончиться слезы, но не смех». Полученные данные способствуют нашему пониманию онлайн-сатиры как жанра, который использует возможности новых медиа для расширения социального потенциала традиционной формы оппозиционного дискурса.
\end{abstract}

Ключевые слова: юмор, политическая сатира, COVID-19, онлайн-сатира, сатирический дискурс, мем

\section{Для цитирования:}

Ponton D.M. "Never in my life have I heard such a load of absolute nonsense. Wtf." Political satire on the handling of the COVID-19 crisis. Russian Journal of Linguistics. 2021. Vol. 25. № 3. P. 767-788. https://doi.org/10.22363/2687-0088-2021-25-3-767-788

\section{Introduction}

To paraphrase Walter Benjamin (2008: 378), man may 'run out of tears but not of laughter'. This paper highlights the emotional dimension of humour, as does Chafe (2007), who speaks of a 'feeling of non-seriousness'. Though the connection of humour to the emotions has been questioned by some (Morreall 1983), this paper argues that satire, as a form of humour, appears to function against the backdrop, and as a release for, a range of feelings (anger, bitterness, disappointment, frustration, anxiety, fear, despair, etc.). Many of these feelings were widely generated by the COVID-19 crisis and political responses to it. 
The paper focuses on political satire in social media, in memes that circulated at a time when the COVID-19 pandemic was having dramatic effects on social behaviour, restricting civil liberties on a scale unknown in western nations since World War II. The rash of comic memes that began to circulate across social media were a predictable response to this unprecedented situation, while in mainstream print media political satirists lampooned the responses of governments to the crisis.

For this paper, there are two relevant approaches to COVID-19 memes: firstly, they may be seen as part of a tradition of 'gallows humour', i.e. humour which attempts to see the funny side of the most desperate circumstances (Peniston-Bird \& Summerfield 2001, Kozintzev 2015). As Goffman (1961: 68) says, gallows humour is a response to 'times and places of stress where matters that are extremely difficult to bear [...] are introduced lightly and ironically.' Some memes of this kind appear to have no ulterior political motive, but simply aim to raise a chuckle (Fig. 1):

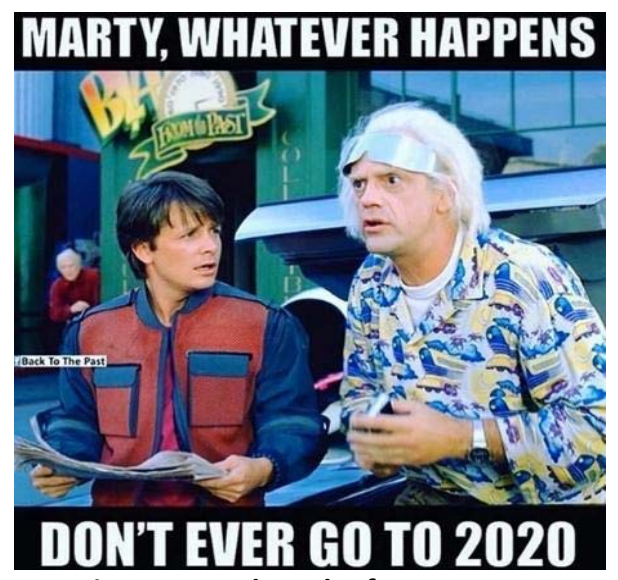

Figure 1. Back to the future meme

This meme circulated in the midst of the crisis, when there was widespread uncertainty over the global impact of the disease, in a moment when it was legitimate to wonder if the apocalypse had arrived (El Maarouf et al 2020). The meme points no accusing finger, but rather arguably works, through humour, to create a sense of solidarity (Jensen et al 2018).

A second perspective sees the memes as part of a satirical discourse genre, whose components' ideal aim is to effect social change. Goffman (op. cit) uses the phrase 'subversive irony' to describe the pragmatic purposes of such humour, which may be seen in traditional forms of media such as printed cartoons. PenistonBird and Summerfield (op. cit), for instance, show how British cartoonists in World War II focused on issues of class and gender inequality, targeting social problems that pre-dated war with the Nazi regime. Later political cartoonists have used their work to suggest that politicians are guilty of a range of crimes that would, in an ideal world, negatively affect their electability ${ }^{1}$.

${ }^{1}$ See, for example, De Sousa \& Medhurst 1982 (who discuss sartire targeting American politicians); Al-Shaikh 2007 (Palestinian cartoons targeting Israelis, the USA, etc.); Bal et al. 2009 
The paper examines a number of image macros and other memes, collected from the internet at various moments in the crisis. It explores the connection of political satire and humour, asking two principle research questions: firstly, how to explain the humorous effects of these multimodal artefacts; secondly, from a pragmatic perspective, how to account for their overall socio-political function.

\section{Context: the COVID-19 pandemic}

COVID-19 is the latest in a series of so-called 'corona' viruses to emerge, the name referring to the crown-like appearance of the virus under an electromicroscope. These viruses have been the cause of two recent human epidemics, Severe Acute Respiratory Syndrome (SARS), in 2003, and Middle East Respiratory Syndrome (MERS) in $2012^{2}$. The virus became known to the global public in late 2019 , with reports emerging from Wuhan, China of a new infectious disease that rapidly began to assume the status of a pandemic (Gates 2020).

Responses to the crisis varied, with some world leaders, notably Trump, Johnson and Bolsonaro initially favouring a laissez-faire approach, apparently aimed at the achievement of 'herd immunity', or a state where the proportion of infected to non-infected members of a population is sufficient to reduce the chances of further spreading (Randolph \& Barreiro 2020). However, as Randolph and Barreiro (ibid.) point out, such policies would have entailed a widespread collapse of healthcare systems, and resulted in millions of deaths. As the crisis evolved, it became apparent that to espouse publicly a policy of 'business as usual' would be politically unacceptable. In most countries, all normal human social activity was suspended indefinitely, including concerts, sporting events, church services, shopping outings, trips to pubs, nature rambles and so on. Most western populations endured 'lockdown', periods of domestic imprisonment with strict limits on their freedom to move. Images of the empty streets of the world's major cities began to appear in media, symbols of the drastic changes that the health emergency was making necessary.

Nevertheless, some countries, among them Sweden, Belarus, South Korea and Japan did proceed with a version of business as usual, introducing certain restrictions but avoiding major shut-downs in industry and other areas of the economy. The fact that key statistics for infections and fatalities, in these countries, did not appear significantly higher than those practising lockdown (Her 2020, Rocklöv in press), arguably lent greater impetus to public resentment towards the lockdown regimes.

Moreover, social media sites such as Facebook and Twitter, which have traditionally been associated with freedom of speech (Rappaport 1998, Sangsuvan 2013), enacted a form of censorship of posts that were judged to be against the

(allegations of rape against ANC leader Jacob Zuma), Bell and Valley 2013 (Gerald Scarfe cartoon showing Netanyahu building a wall), etc.

2 European Centre for Disease Prevention and Control. https://www.ecdc.europa.eu/en/ covid-19/latest-evidence/coronaviruses (Accessed: 05.08.2020). 
public interest. This applied to conspiracy theories of various kinds, including claims that $5 \mathrm{G}$ technologies had a role in spreading the virus, or that shadowy global èlites were using the crisis to entrench their power ${ }^{3}$. Such material is part of a growing debate over ab/use of the internet as a means of spreading fake news, or mis-information (Ferrara 2015, 2020). However, the reduction of the flow of information to messages that accorded with a pro-lockdown, pro-social distancing orthodoxy undoubtedly enhanced the satirical potentialities of alternative communication through social media.

This is the context knowledge, shared between meme producer and online consumer, that is a fundamental pre-condition for any type of humour (Dolitsky 1983).

\section{Political satire}

Political satire has a long tradition, dating back to the ancient Greeks (Rosen 2007) and Romans (Kennedy 1994, Hooley 1997). In tolerant regimes, the satirist is permitted to use humour to speak the truth to power: as Gilbert Highet (in Gruner 1965: 149) puts it: 'the purpose of satire is, through laughter and invective, to cure folly and to punish evil'. In an empirical study, Plevriti (2013: 18) confirms that many of today's meme creators view their activity in these terms. Many aim to unmask rotten politicians, to 'raise awareness about situations they [deem] as in need of change and improvement', while their predominant purpose is reported as 'to use satirical humor as public commentary', to expose 'dysfunctional politics', and defend 'what they see as just'.

Though satire is both entertainment and political criticism, it has been suggested that there is an inverse relationship between these two functions; i.e. that the funnier people find the satire, the less they are able to perceive its essential message (Gruner 1965). It should also be remembered that political satire is apt to awaken the viewer's political affiliations, so that an attack on a politician's private morals may be interpreted in political terms, as an attack on their party ${ }^{4}$.

However, studies have shown that exposure to political satire in television or other media may increase levels of political knowledge and engagement (Hardy et

3 See, for instance, the site Cosmos Chronicle, online at: https://cosmoschronicle.com/ operation-covid-19-stands-for-a-militarized-world-takeover-scheme/ (Accessed: 05.08.2020), which makes sweeping claims such as: ... when people find out that the wealthy elites have secretly protected themselves from the COVID-19 bio-weapon they recklessly let loose on humanity, that's when folks will really get mad.../...every person on planet Earth is living through an AI-simulated global live exercise where covert acts of bio-terrorism are stealthily blended with staged hoaxes.../, and so on.

${ }^{4}$ This consideration may work against the idea that a political satirist's exposing the 'truth' will lead to change. For example, during the Clinton / Lewinsky scandal, widely satirised at the time (see, for instance Clinton: his struggle with dirt (https://www.youtube.com/watch?v= U91s4S5S_Ck (Accessed: 02.08.2020)), the facts of the case soon reached the public domain but, from a historical perspective, appear to have been widely interpreted by the American people along party lines. See Mitchell et al (2014) for a general outline of the impact of media on the political opinions of viewers. 
al. 2014: 331). Feldman and Young (2008) report that interest in the US presidential election was higher among viewers of late night comedy programmes than the general population. Moreover, Young (2013: 181, in Hardy et al. 2014: 331), cites cognitive studies ${ }^{5}$ that indicate the role of humour in covertly shaping political attitudes:

Because humor often involves the intersection of an established frame of reference with an incongruous, unexpected one, scholars have posited that comprehension and appreciation of humor fosters attention and recall by default

From a perspective of political persuasion ${ }^{6}$ these studies are significant because they suggest that the satirist may be able to affect, to a greater or lesser degree, the political views of meme consumers.

Again, Knobloch-Westerwick and Lavis (2017: 69) advance the suggestion that, through satire, viewers might 'engage more with counterattitudinal views and broaden their understandings of political issues'. This assertion, if correct, lends further support to claims that political memes circulating on the internet have a role in shaping the global cultural and political landscape (Jenkins, Ford \& Green 2013: 44).

Our minds are invaded by memes, as ancient bacteria invaded our ancestors' cells and became mitochondria. Cheshire Cat-like, memes merge into our minds, even become our minds (Dawkins 1999)

The concept of memes originated with Dawkins' (1976) work on genetic transmission. The biologist hypothesised that, just as biological information is passed from one being to another through DNA, a range of socio-cultural attitudes including political and religious views may be transmitted through memes, which also have the potential, as the above quote argues, to affect consumers' minds without reference to their will (see also Way 2021, this issue). In our time, memes are 'multimodal symbolic artifacts' (Milner 2013: 2359) that are distinguished from earlier satirical forms (such as the political cartoon), in that they exploit the affordances of Web 2.0 to create virtual communities of meme creators, sharers and consumers ${ }^{7}$. As Milner (2013) points out, processes of meme production and exchange bypass problems of access associated with traditional forms of media, since anyone with minimal computer skills and an internet connection can participate.

${ }^{5}$ The research cited is from educational contexts, and claims are made that humour increases information retention and other learning outcomes (Kaplan and Pasco 1977, Ziv 1988, Garner 2006).

${ }^{6}$ The perspective referred to here is that of studies which suggest a form of covert persuasion through mediated exposure to political views, e.g. Fowler 1991, Halmari and Virtanen 2005, Gilbert et al 2013, Larina, Ozyumenko and Ponton 2020.

${ }^{7}$ For a discussion of the evolution of meme culture from its beginnings to the present day, see the article in the Guardian Online: Amalia Tait. https:/www.theguardian.com/commentisfree/2017/sep/ 12/leave-britney-alone-prototype-viral-hit-chris-crocker (Accessed: 14.08.2020). 
In most memes, traditional media content (such as political slogans, videos, pop songs, movie scenes, images involving celebrities, sporting or high profile news events, etc.) are remixed in an intertextual blend (Shifman 2014) that draws on such cultural content, as well as prior user knowledge, to alter the original message or add a specific communicative spin (Plevriti 2013). Where the communicative intent relates to politics, a critical evaluation of the phenomenon in question is offered; such evaluation may be positive but is more often satirical, as discussed above.

\section{Data and methodology}

Over the first 18 months from the beginning of the lockdown period, which in Italy began in March 2020, approximately 100 COVID-19 memes were collected from various online sources (Facebook, Twitter, Google, etc.). These were analysed according to a mixed approach that blends notions from Humour studies, especially incongruity (Morreall 2016), with insights from linguistic pragmatics (e.g. Kecskes 2014). The findings emphasise the emotional dimension of this form of satire.

A notion current in Schopenhauer's time, and still a focus of contemporary humour studies, is that of incongruity (Morreall 1989, Winter 1994: 60, Forabosco 1992, Simpson 1998, Ritchie 2003, Attardo 2019: 197-8). Though humour theory has explored many other pathways, the following is still a relevant perspective:

The cause of laughter in every case is simply the sudden perception of the incongruity between a concept and the real objects which have been thought through it in some relation, and laughter itself is just the expression of this incongruity (Schopenhauer 1818:76).

The suggestion that incongruity alone may constitute a sufficient explanation for the humorous effect is unsatisfactory, since there are types of incongruity that may not provoke laughter; for example, spotting a military tank parked outside a supermarket among the other cars, or a seagull at a garden bird table. In some cases, though, incongruity may be a significant factor in the humorous effect. As an example, consider a vicar appearing in church in football kit. The humour and satirical effect in this case, and in that of many internet memes, arguably, function thanks to the incongruity arising from the juxtaposition of experiential domains (Marín-Arrese 2008, 2015; see also Canestrari and Bianchi 2013: 8-9). There are analogies here with cognitive theories regarding the operation of metaphor, through the 'conceptual mapping of two experiential domains' (Androutsopoulos 2009: 48). Associations of an object in the source domain are applied to one in the target domain (Lakoff 1987, 1993; Lakoff and Johnson 2003), and some such processes appear to apply to the interpretation of satirical memes. Interpretation of both metaphors and memes involves considerations of what is communicatively salient in the comparison, another concept familiar from cognitive studies (Haslam et al 1999, Bach 2007, Kecskes 2014: 24, 2016). Some possible sterotypical associations of the footballer that might provoke amusement when applied to a vicar are that 
footballers run around a lot in games, they become sweaty, they spit, in some cases they commit bad actions (fouls), use bad language, have promiscuous life-styles, and so on.

Morreall (2016) shows how Grice's pragmatic maxims (Grice 1989) may be used to explore humorous effect (see also Simpson 2009). He equates incongruity with 'the violation of our mental patterns and expectations', and says that humour may arise when the maxims are flouted. This paper focuses on violations of Grice's maxims of Relation and Manner:

The maxim of relation, where one tries to be relevant, and says things that are pertinent to the discussion.

The maxim of manner, when one tries to be as clear, as brief, and as orderly as one can in what one says, and where one avoids obscurity and ambiguity (Grice 1975)

Ambiguity, for example, is the mainspring of many jokes, which exploit double meanings of words, as in Mae West's line (cited in Morreall 2016): "Marriage is a great institution-but I'm not ready for an institution." The recommendation for brevity is flouted by the long joke, or 'shaggy dog story', and so on.

As an example of this methodological approach, consider the following image macro, where the target is Boris Johnson, Britain's Prime Minister at the time of COVID-19 (Fig. 2).

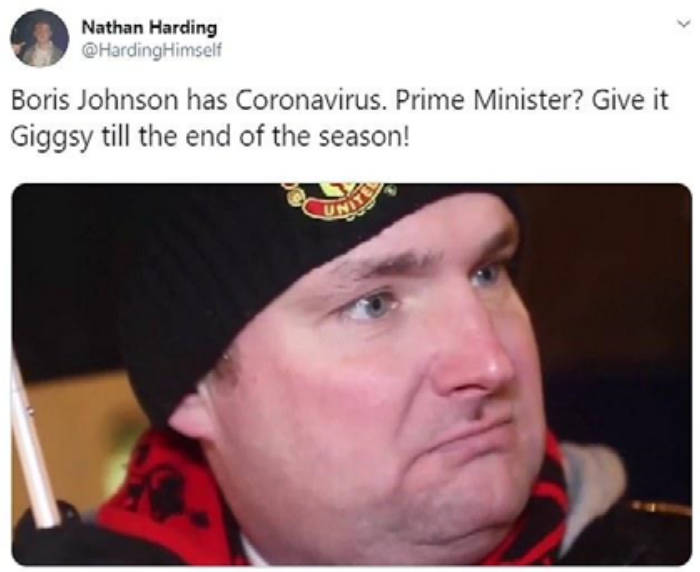

Figure 2. Give it Giggsy

'Giggsy' is Ryan Giggs, a prominent ex-footballer from Manchester United. The text purports to be posted by the fan in the photo, whose thoughts are indicated in the accompanying text; it mimics pundit talk about managerial vacancies. Incongruity arises from the fan's suggested solution: 'Give it Giggsy till the end of the season!', which flouts the maxim of Relation (hereafter, MR), since Giggs obviously lacks the qualifications to stand in for Johnson. The discourse is thus defective in some way, and in such instances one hypothesis, that it is intended as a joke (Kapogianni 2011), supplies a possible explanation, the hypothesis strengthened by the exclamation mark. 
In terms of the juxtaposition of experiential domains, what is salient is Johnson's prominent role in the political world, where key decisions must be made, affecting the lives of many people. By contrast, the world of soccer is pure entertainment, a circus which provides temporary escape from real-world issues for millions.

By suggesting that 'Giggsy' would be an able substitute, therefore, the meme undermines the role of the Prime Minister, and indeed, the political realm in general. The perspective of the satirical BBC TV show 'Yes Minister' (Granville 2009) is relevant here: the programme showed that real power in Britain is exercised by civil servants, while narcissistic politicians of different parties come and go, competing for public attention through speeches, photo ops, TV appearances and so on (Street 2001, Van Zoonen 2005). As Apter (2006: 223) says:

Political theatre, like its more general counterpart, can be variously tragedy, melodrama, farce, romance, and comedy with elements of each incorporated in a single dramatic instance

By blending two discrete social domains through their respective linguistic genres (political discourse and football talk), the image macro also represents Johnson as a dismissed football manager, insinuating that he is not even capable of running a football club, still less a nation. ${ }^{8}$

\section{Data analysis}

\subsection{COVID-19 memes}

In figure 3 are some popular image macro memes that circulated during the crisis period, with juxtaposition of domains indicated below each.

In (1), the effect of incongruity derives from: temporal dislocation, a modern policeman superimposed on a sample of Renaissance art depicting biblical figures. Spatial dislocation: this painting is situated on the ceiling of the Sistine Chapel, therefore the pose of the policeman would be impossible. Thematic dislocation: the painting is Michelangelo's rendering of the Genesis story, God passing the vital spark of life to Man, while the meme shows his creation, thousands of years later, in the act of fining his creator. The salient point appears to be the notion of physical contact, which is problematised, due to the presence of the policeman. Interpretation could involve viewers in the following inferential steps (see Giora 1991, Kearns 2000: 895):

- The policeman is noting an offence (therefore the figures in the foreground must be breaking the law);

- They appear to be touching (and since, due to the COVID-19 situation, physical contact is not allowed);

- This explains the policeman's actions.

${ }^{8}$ In terms of Van Leeuwen's theorisation of the representation of social actors, the meme could illustrate a sub-category of overdetermination, in which the characteristics of one typology of social actor are superimposed on a person from a different category (Van Leeuwen 2008). 


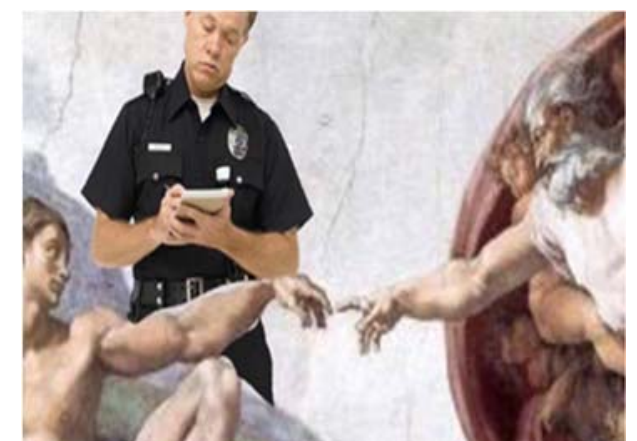

(1) Policing / High Art

ALL OF A SUDDEY

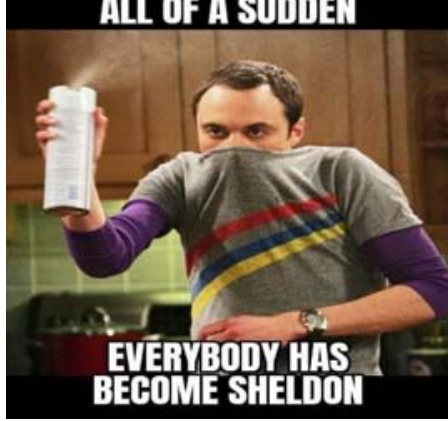

(3) Popular culture/ Covid crisis

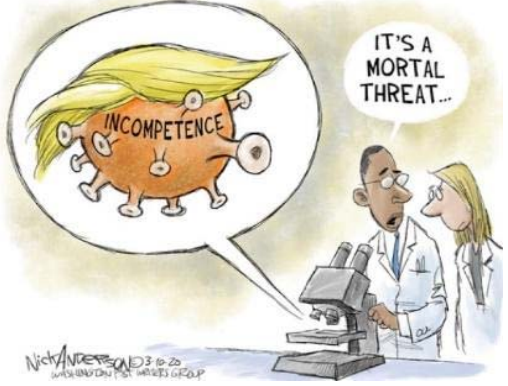

(5) Politics /Medicine

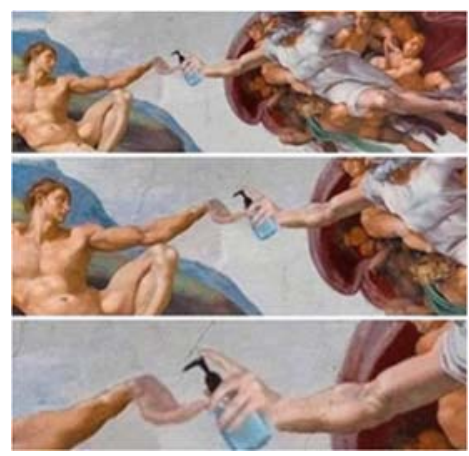

(2) Mundane objects / High Art

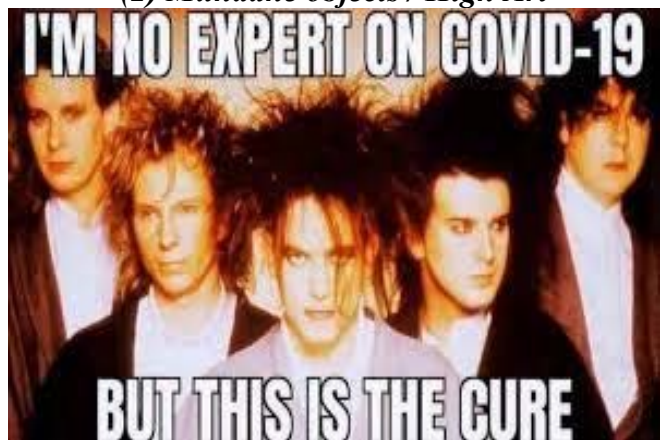

(4) Popular culture/ Medicine

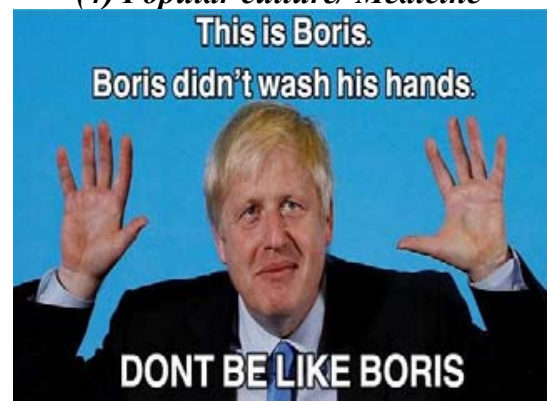

(6) Junior school / Politics

Figure 3. Some COVID-19 memes

It is harder to explain why this is funny, though the notion that God, had he obeyed the draconian measures introduced by world governments, may not have been able to create the world in the first place, may account for this. This meme is a kind of reductio ad absurdem, protesting against the over-zealous prohibitions imposed during the crisis. The meme in (2) covers identical ground; here, the salient feature is made explicit by the use of narrowing frames, that direct the viewers' attention to the hand sanitiser. The ultimate authority figure (God) is thus aligned with the paternalistic and restrictive responses of governments.

Meme (3) depends on shared knowledge of the US television comedy 'the Big Bang Theory'; salient is the character Sheldon's phobia for germs. The meme differs from the others in that there is apparently no effect of incongruity; in fact, during the crisis, people did take more precautions. Since, however, Sheldon is 
portrayed as neurotically hyper-sensitive, the meme satirises the over-reactions of ordinary people in this area.

Meme (4) is an example of non sequitur humour, that simply exploits the medical connotations of the band's name.

The last two are overtly political. In (5) Trump is identified with the virus, which shares some of his physical characterics (hair and pouting lips). The meme leaves ambiguous the question of whether it is Trump himself, or simply his 'incompetence' which are to be seen as a 'mortal threat'.

In (6), Johnson is cast as a junior schooler, through the text's borrowing from the 'cautionary tale' genre (Belloc 1979), which provides behavioural models for children. Johnson who, as viewers will know, himself contracted COVID-19, is ridiculed as immature, his handling of the crisis called into question.

These are samples of the genre, with some comments highlighting the pragmatic features of interpretation; it is not suggested that the selection is comprehensive nor representative. My intention is not to provide such an overview; rather, it is to show how a pragmatic perspective may be useful to explicate the construction and reception of meaning in each case.

\subsection{Sarah Cooper Trump memes}

In the lockdown period, a series of memes began to appear on Tik-Tok, YouTube and other social media platforms, in which comedienne Sarah Cooper lipsynchs brief utterances by US president Donald Trump, including his remarks on the COVID-19 crisis. On 23 April 2020, at a White House COVID briefing, Trump appeared after William Bryan of the Homeland Security Department, who had spoken of the effects of sunlight on the virus. The president's speech is rather incoherent, but he appears to be commending the use of ultra-violet light and bleach in treating COVID, and his remarks seem to have been understood in this sense by many listeners. ${ }^{9}$ Studies conducted following his remarks (Gharpure et al 2020) found that many Americans had already been using household cleaning products to protect themselves from infection, through extensive cleaning, but also in ways that included gargling or in extreme cases, ingestion. ${ }^{10}$

The text of Trump's remarks, used by Cooper, is as follows:

So, supposedly we hit the body with a tremendous, whether it's ultraviolet or just very powerful light, and I think you said that hasn't been checked, but you're going to test it. And then I said supposing you brought the light inside the body, which you can do either through the skin or in some other way. (To Bryan) And I think you said you're going to test that, too. Sounds interesting, right? And then I see the disinfectant, where it knocks it out in a minute. One minute. And is there a way we can do something like that, by injection inside

${ }^{9}$ The Independent. https://www.independent.co.uk/news/world/americas/coronavirus-disinfectantdrink-bleach-covid-19-atlanta-georgia-a9489566.html, (Accessed: 25.07.2020).

${ }^{10}$ Sky News. https://news.sky.com/story/coronavirus-americans-drinking-and-inhaling-bleachto-try-to-prevent-covid-19-infections-study-12002236 (Accessed: 25.07.2020). 
or almost a cleaning, because you see it gets in the lungs and it does a tremendous number on the lungs, so it'd be interesting to check that, so that you're going to have to use medical doctors with, but it sounds interesting to me.

One important feature of this type of political satire is that it uses the president's actual words; it cannot be objected that words are being put in his mouth, that 'he never said that'. Let us begin by discussing incongruity in the first image of Cooper, below (Fig. 4):

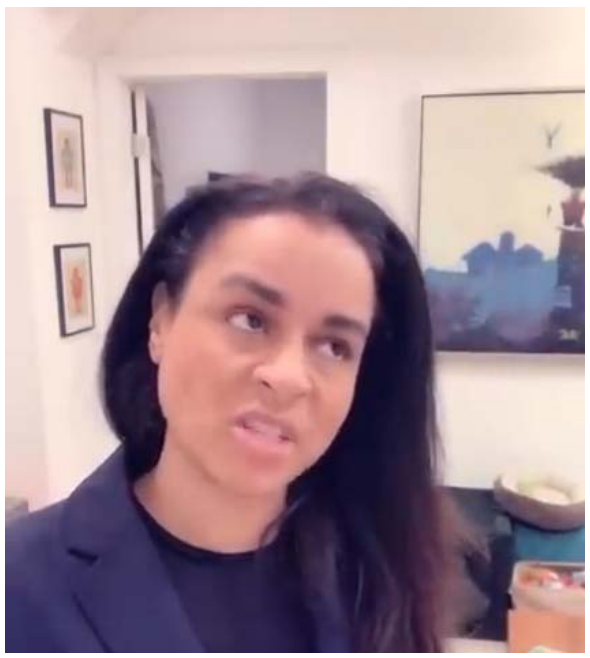

Figure 4. Sarah Cooper (i)

The most striking source of incongruity regards gender; the listener hears a male voice emerging from a female character. It is, however, also an instantly recognisable voice, that of the most prominent figure in American public life, which appears to belong, in these videos, to an unknown. Moreover, Trump is a white American; here, the character is black. The setting, too, construes incongruity, since Trump was speaking at a press conference, in a formal, public context, while here the scene is the interior of a typical apartment.

There is also incongruity in the discourse of Trump himself who, as has been pointed out, appears to lack control over the aspect of communicative register. ${ }^{11} \mathrm{As}$ a prominent social actor in an institutional setting, the language of a president of the United States ought to be formal, correct, informed and accurate; in a crisis it should consist of responsible statements that offer a guide to citizens, explain public policy and justify unpopular choices. Instead, Trump's linguistic behaviour is typical of a private conversation among peers (sounds interesting, right?), including colloquial rather than technical terminology (it knocks it out in a minute, it does a tremendous number on the lungs), and a subjective rather than a scientific perspective (and then I said, etc.) (see Sclafani 2017). This linguistic profile is consistent with Trump's populist, anti-intellectual political position (Kayam 2017).

11 See the comments of linguist John McWhorter. https://www.youtube.com/watch? $v=$ Qwnpa3KhT4Y (Accessed: 16.08.2020). 
From a pragmatic perspective, Trump's remarks appear to flout Grice's two maxims at many points. For instance, the obscurity of expression (Maxim of Manner, hereafter MM) in the opening:

(1) Supposedly we hit the body

The adverb/adjective 'supposedly' means 'it is/was supposed'. It usually construes counterfactuality, as in this example taken from the internet:

(2) The desert, this supposedly most hostile of all places, becomes the setting for free love

In temporal terms, the verbal choice 'hit' could refer to the past tense, so one possible meaning for this utterance could be:

(3) (in our experiment) [people said that we] subjected the body to.. (in fact, we did not)

The co-text makes it plain that Trump is referring to a future project (that hasn't been checked, but you're going to test it). Therefore, 'supposedly' is used to mean something like 'somebody has proposed a future course of action', a meaning which it may have, but only in the context of informal conversation ${ }^{12}$. What the president actually means appears to be something like: a plan has been advanced which will involve hitting the body with, a meaning which also suffers from vagueness due to the passive formulation, which does not specify the identity of those making the plan.

Trump is also vague (MM) in the pronoun 'we', which could refer to many social actors (some possibilities are US researchers, the Homeland Security Department, medical specialists generally, etc.).

Another source of confusion (MM) immediately follows:

(4) with a tremendous, whether it's ultraviolet or just very powerful light

Salient here appears to be the power of the light, but to speak of 'tremendous' or 'very powerful' is to use non-technical language, while 'ultra-violet' is more technical but is only introduced as a possibility, through the 'whether..or' construction. The effect is a) that the speaker is providing information which is imprecise (what exactly is meant by 'a very powerful light'?), and b) that he is uncertain of the details of the proposal.

The whole discourse is characterised by comparable breaches of Grice's maxims, so that it really is hard to follow the speaker's meaning, or tease it out with any certainty:

${ }^{12}$ Exploring the hits for 'supposedly' in the British National Corpus (https://www.englishcorpora.org/bnc, (Accessed: 16.08.2020)), there appears to be a distinction between spoken and written English. In the latter, the meaning 'was supposed to have' is common, with the counterfactual inference fairly frequent. In spoken English it appears that a general meaning of 'future possibility' may be indicated, as in: 'Well supposedly she'll come tomorrow night anyway'. 
(5) And then I see the disinfectant, where it knocks it out in a minute

Trump appears to be giving a brief summary of discussions had with Bryan (I think you said, then I said, I think you said). Here, however, the temporal frame shifts to the present (then I see), implying something that happened at a time following the discussions with Bryan, or at least, at the same time. In formal terms, the implied meaning could be something like: 'the results of recent scientific tests have suggested that disinfectant is capable of eliminating the virus in one minute'. However, the colloquial register and lack of precision create an effect of ambiguity (MM); it could be that the president is referring to some unscientific notion, picked up from hearsay or a media report of some kind, possibly at a time successive to the discussions with Bryan.

Trump's final recommendation, that Bryan should 'use medical doctors' for this research, arguably flouts a different maxim, possibly subsumed under the maxim of manner, which could be expressed as 'do not waste listeners' time by stating the obvious'.

The above cursory analysis of Trump's discourse is by way of an introduction to an exploration of Cooper's satirical presentation, since her method seems to focus attention precisely on points where the speech is deficient, from a Gricean perspective. In other words, her gestures, facial expressions and the construction of the video highlight the ambiguity and/or obscurity of the discourse itself.

1

$0.00-0.03$

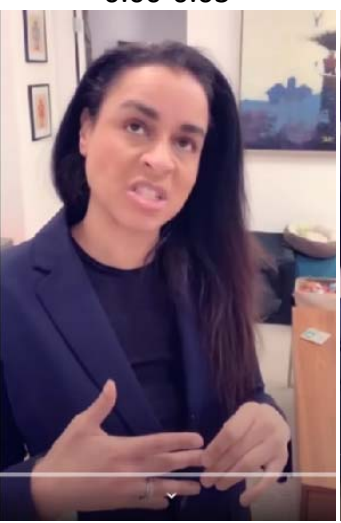

We hit the body with a tremendous, er..
2

$0.03-0.07$

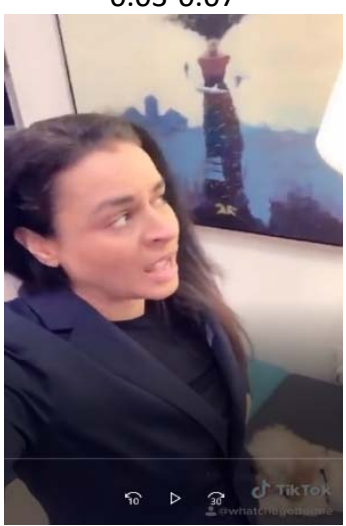

whether it's ultraviolet and I think you said that or just very powerful light hasn't been checked,
3

$0.07-0.10$

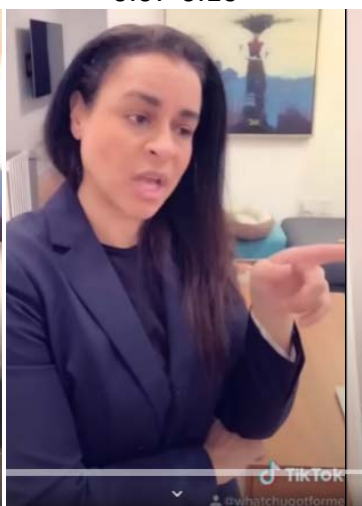

to test it.

4

$0.10-0.12$

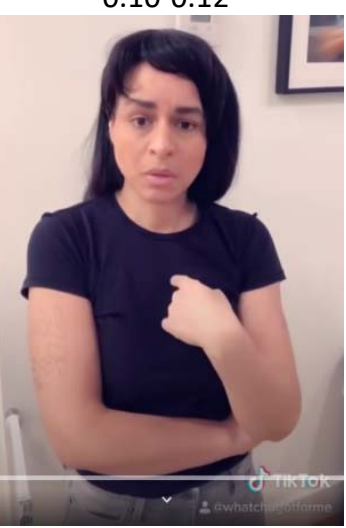

but you're going

Figure 5. Sarah Cooper lip-synch (i)

In figure 5 (1), Cooper's gaze shifts upwards and moves from left to right in the characteristic gestures of someone searching for the right word. The hands meet in a 'self-touching gesture' (Kimura 1976), which may indicate nervousness, discomfort or boredom (Krauss et al. 1996: 393). Cooper's roving gaze encounters a large standing lamp (4.2), while she is talking about 'light', thus associating the speaker with the absurd notion that a household lamp might be used in a medical 
context. Then, when the president's discourse concerns Bryan ("I think you said"), she points to a bystander whose gaze and gestures indicate denial of involvement by miming "who me?" (4.4). The inference is that Trump is out of synch with his scientific/medical advisers.

Trump continues with suggestions that the light can be brought 'inside the body'; again, note the everday language used, which contrasts with the precise, scientific terminology that would clarify exactly what is going on. As he struggles to 'explain' how this might work, Cooper's arm gestures are sweeping $(5.1,2)$, her hands briefly indicate mouth, eyes, ears, and end up pointing at her behind (5.3-4) (Fig. 6).

1

$0.12-0.14$

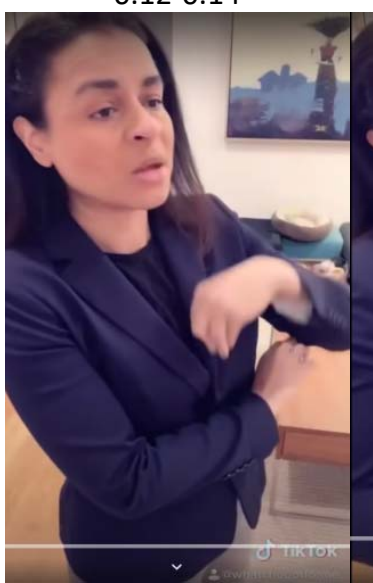

supposing you brought the light inside the body
2

$0.14-0.15$

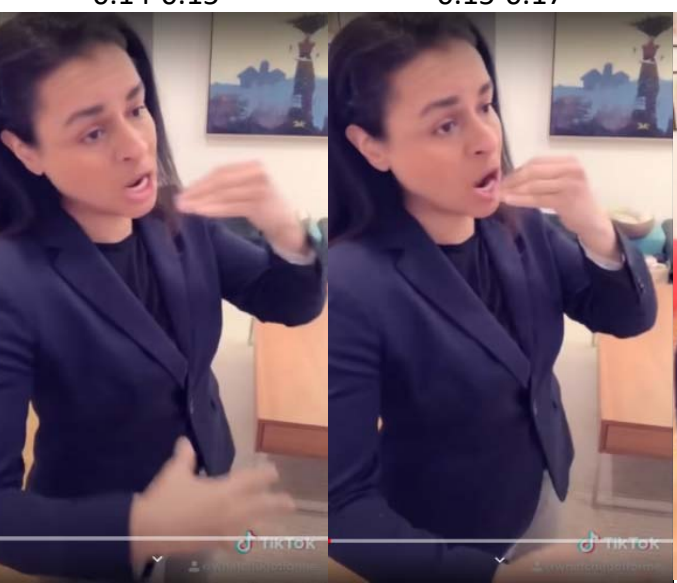

which you can do either through
3

$0.15-0.17$

the skin or, er

Figure 6. In some other way

There is a significant pause at $0.16-0.17$ (4.3), marked by Trump's hesitation marker 'er', before the final hand gesture. The actress' gestures in this sequence suggest that Trump has no precise idea of how light is to be brought inside the body (if he knows, then why point to so many different bodily orifices?); the final irreverent pose suggests that Trump has been talking through his behind.

\section{Conclusion}

The question of why something is funny has not yet been fully answered by researchers in humour studies, nor are incongruity theories proposed as complete explanations (Latta 1999, Dynel 2013: vii). It may seem curious, in a time of global pandemic, to find enjoyment in memes that deal directly with events that have provoked such universal misery. However, as we stressed above, to laugh at a perceived danger, or seek humour in distressing circumstances, are coping mechanisms (see Young 1995). The humorous impact of COVID-19 memes, arguably, may be related to a wish for some kind of prophylactic magic; through 
laughter, fear is exorcised, and at a superstitious level, the anticipated future disaster may be avoided. Humour theorists, from the time of Freud, have suggested that our sexual anxieties, weaknesses and foibles may constitute the bedrock of the humorous experience, as we seek therapeutic relief or catharsis for these emotions and states of being (Freud 1976, Billig 2002, Brottman 2004).

One of the consistent features of political satire, from its ancient origins until today, has been a socially levelling effect, showing the feet of clay on which our masters walk. People like priests, politicians, doctors and the like are fair game for satire because they are normally in positions of power over the rest of us. A vicar, for example, is surrounded by symbols of his moral authority, crucifixes and holy images, the bible and other sacred objects on the altar, and so on. When this authority is temporarily undermined by a satirical gesture such as his appearance in football kit, as discussed above, we may find it amusing because for a moment a weight is lifted, for a moment we breathe freely. In this perspective, and to return to the emotional aspect of humour, to laugh is an expression of sudden joy ${ }^{13}$.

These reflections would account for the humorous effect of Cooper's depictions of Trump, for example. The US president has been a heavily mediated presence for some years, who has acquired enormous symbolic power over the mediated spaces we all share, through internet, television and so on (Way 2021, this issue). The incongruities in Cooper's sketch remove at a stroke many of the trappings of Trump's greatness - the mediated image, the familiar institutional settings, the celebrities that surround him. We recognise Trump, in these videos, only through the voice, and are therefore free to focus more directly on the content of what is said. By situating the speech in an everyday apartment, Cooper invites us to see the protagonists as endowed with no more social power than our neighbours. All this prepares us to respond to the most important incongruity on show; the disparity between expectation and reality in terms of the linguistic content of the speech. People look to their leaders for reliable information and strong leadership; what Trump actually offers is confused, semi-coherent rambling and medically dangerous suggestions. This, in reality, is not funny. However, I suggest that we laugh because the temporary release from our normal state of subjection to such figures, allows us to engage in a form of humorous response normally reserved for our peers or social inferiors - mockery (Haugh 2010). The same comments apply, mutatis mutandis, to the numerous memes circulating on the internet attacking other prominent politicians during the crisis, such as Johnson or Bolsonaro.

Finally, it is worth pondering the question of how effective such satire might be in the pragmatic terms of bringing about the desired perlocutionary result sought by the satirist. In the case of the Cooper memes, which appear in the election year of 2020, it is clear that the comedienne is pushing a subliminal message that could be stated as follows: our current leader is incompetent. Do not vote for him, but

${ }^{13}$ The Catholic sketches of Irish comic Dave Allen exemplify what I am talking about here. 
vote for a more suitable leader. For Johnson memes, the message is much the same; translated into political terms, it means vote for the opposition.

Memes, as was mentioned above, may figure among persuasive multimodal genres with a specific political purpose in terms of influencing opinions and behaviour. Clearly, reception of such artefacts depends, to a great extent, on the recipients' political orientation: Democrats will love the Trump memes, since they are hostile to Trump, Republicans will reject them for the same reason. Arguably, the battleground is for the undecided and, though it is impossible to trace the specific effects of any single meme, it is probable that, as we mentioned above, memes do have the potential to shape the global cultural and political landscape (Jenkins, Ford \& Green 2013: 44). The vision of Trump portrayed by Cooper is of a bumbling figure, out of touch with his advisers. The meme will find its place among a host of other memes pushing a similar view; it will be re-tweeted, shared, uploaded to users' facebook pages, commented on, liked, disliked, and so on. Whether all this will change a single voter's mind is unclear, and is not really the point, which is rather that political satire has always aimed at proclaiming, and illustrating, the truth. How people respond to that is their business.

The findings thus emphasise the emotional dimension of this form of satire, as the memes work against the backdrop of a range of feelings (anger, bitterness, disappointment, frustration, despair, etc.), many of which have been widely generated by the COVID-19 crisis and political responses to it. The findings contribute to our understanding of online satire as an emergent genre, one that uses the affordances of new media to extend the social potentialities of a traditional subversive discourse form.

(C) Douglas M. Ponton, 2021
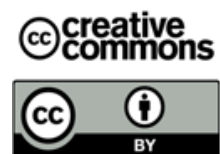

This work is licensed under a Creative Commons Attribution 4.0 International License https://creativecommons.org/licenses/by/4.0/

\section{Acknowledgments}

This publication has been supported by the RUDN University Strategic Academic Leadership Programme.

\section{REFERENCES}

Al-Shaikh, Abdul-Rahim. 2007. Historiographies of laughter: Poetics of deformation in Palestinian political cartoon. Third Text 21 (1). 65-78.

Androutsopoulos, Jannis. 2009. Language and the three spheres of Hip Hop. In Alim H. Samy, Awad Ibrahim \& Alastair Pennycook (eds.), Global Linguistic Flows Hip Hop Cultures, Youth Identities, and the Politics of Language, 43-63. Abingdon/New York: Routledge.

Apter, David E. 2006. Politics as theatre: An alternative view of the rationalities of power. In Jeffrey C. Alexander, Bernhard Giesen \& Jason L. Mast (eds.), Social Performance, 
Symbolic Action, Cultural Pragmatics and Ritual, 218-257. Cambridge: Cambridge University Press.

Attardo, Salvatore. 2019. Humor and mirth: Emotions, embodied cognition, and sustained humor. In Mackenzie J. Lachlan \& Laura Alba-Juez (eds.), Emotion in Discourse, 189-213. Amsterdam: John Benjamins.

Bach, Kent. 2007. Regressions in pragmatics (and semantics). In Noel Burton-Roberts (ed.), Pragmatics (Advances in Linguistics), 22-44. Palgrave-Macmillan: Basingstoke.

Bal, Anjali S., Leyland, Pitt, Pierre, Berthon \& Philip Des Autels. 2009. Caricatures, cartoons, spoofs and satires: Political brands as butt. Journal of Public Affairs 9. 229-237.

Belloc, Hilaire. 1979. Hilaire Belloc's Cautionary Tales. Boston: Gregg Press.

Bell, Steve \& Eli Valley. 2013. Drawing truth to power: A conversation about cartoons between Steve Bell and Eli Valley. Jewish Quarterly 60 (1). 28-33.

Benjamin, Walter. 2008. The Work of Art in the Age of its Technological Reproducibility, and other Writings on Media. Cambridge, Mass.: Belknap Press.

Billig, Michael. 2002. Freud and the language of humour. The Psychologist 15 (9). 452-455.

Brottman, Mikita. 2004. Funny Peculiar: Gershon Legman and the Psychopathology of Humor. Hillsdale: Analytic Press.

Canestrari, Carla \& Ivana Bianchi. 2013. From perception of contraries to humorous incongruities. In Dynel, Marta (ed.), Developments in Linguistic Humour Theory, 3-25. Amsterdam: John Benjamins,

Chafe, Wallace. 2007. The Importance of Not Being Earnest: The Feeling behind Laughter and Humor. Amsterdam and Philadelphia: John Benjamins.

Dawkins, Richard. 1976. The Selfish Gene. Oxford: Oxford University Press.

Dawkins, Richard. 1999. The Selfish Meme. Time International 11 April 1999. http://content.time.com/time/magazine/article/0,9171,22988,00.html (accessed: 28 July 2021).

De Sousa, Michael A. \& Martin J. Medhurst. 1982. Political Cartoons and American Culture: Significant Symbols of Campaign 1980. 8 (1), 84-97. https://repository.upenn.edu/svc/ vol8/iss 1/9 (accessed: 29 July 2020).

Dolitsky, Marlene. 1983. Humor and the unsaid. Journal of Pragmatics 7. 39-48.

Dynel, Marta. 2013. A view on humour theory. In Dynel, Marta (ed.), Developments in Linguistic Humour Theory, vii-xiv. Amsterdam: John Benjamins.

El Maarouf, Moulay Driss, Taieb, Belghazi \& Farouk El Maarouf. 2020. COVID-19: A critical ontology of the present. Educational Philosophy and Theory 53 (1). 71-89. https://www.tandfonline.com/doi/full/10.1080/00131857.2020.1757426 (accessed 29 July 2021).

Feldman, Lauren \& Donnagal G. Young. 2008. Late-night comedy as a gateway to traditional news: An analysis of time trends in news attention among late-night comedy viewers during the 2004 presidential primaries. Political Communication 25 (4). 401-422. https://www.tandfonline.com/doi/abs/10.1080/10584600802427013 (accessed 29 July 2021).

Ferrara, Emilio. 2015. Manipulation and abuse on social media. SIGWEB Newsletter (4). 1-9. https://dl.acm.org/doi/10.1145/2749279.2749283, (accessed 29 July 2021).

Ferrara, Emilio. 2020. What Types of COVID-19 Conspiracies are Populated by Twitter Bots? First Monday https://firstmonday.org/article/view/10633/9548, (accessed 29 July 2021).

Forabosco, Giovannantonio. 1992. Cognitive aspects of the humor process: The concept of incongruity. HUMOR. International Journal of Humor Research 5 (1). 45-68.

Fowler, Roger. 1991. Language in the News: Discourse and Ideology in the Press. London/New York: Routledge.

Freud, Sigmund. 1976. Jokes and their Relation to the Unconscious. Harmondsworth: Penguin. 
Garner, R. L. 2006. Humor in pedagogy: How ha-ha can lead to aha!. College Teaching 54 (1). $177-180$.

Gates, Bill. 2020. Responding to COVID-19-a once-in-a-century pandemic? New England Journal of Medicine 382. 1677-1679.

Gharpure, Radhika, Hunter Candis M., Schnall Amy H., Barrett Catherine E., Kirby Amy E., Kunz Jasen, Berling Kirsten, Mercante Jeffrey W., Murphy Jennifer L. \& Garcia-Williams Amanda G. 2020. Knowledge and practices regarding safe household cleaning and disinfection for COVID-19 prevention - United States, May 2020. MMWR. Morbidity and mortality weekly report, 69 (23). 705-709. https://doi.org/10.15585/mmwr.mm6923e2.

Gilbert, Daniel T., Romin W. Tafarodi, \& Patrick S. Malone. 1993. You can't not believe everything you read. Journal of Personality and Social Psychology 65 (2). 221-233.

Giora, Rachel. 1991. On the cognitive aspects of the joke. Journal of Pragmatics 16. 465-85.

Goffman, Erving. 1961. Encounters: Two Studies in the Sociology of Interaction. Harmondsworth: Penguin.

Granville, Shannon. 2009. Downing Street's favourite soap opera: Evaluating the impact and influence of Yes, Minister and Yes, Prime Minister. Contemporary British History 23 (3). 315-336. https://doi.org/10.1080/13619460903080135.

Grice, Paul. 1989. Studies in the Way of Words. Cambridge, Mass./London: Harvard University Press.

Gruner, Charles R. 1965. An experimental study of satire as persuasion.

Gilbert, Daniel T., Romin W. Tafarodi \& Patrick S. Malone. 1993. You can't not believe everything you read. Journal of Personality and Social Psychology 65 (2). 221-233.

Gruner, Charles R. 1965. An experimental study of satire as persuasion. Speech Monographs. 32 (2). 149-153.

Halmari, Helena \& Tuija Virtanen. 2005. Persuasion Across Genres: A Linguistic Approach. Amsterdam: John Benjamins.

Hardy, Bruce W., Jeffrey A. Gottfried, Kenneth M. Winneg \& Kathleen H. Jamieson. 2014. Stephen Colbert's civics lesson: How Colbert super PAC taught viewers about campaign finance. Mass Communication and Society (17). 329-353. https://doi.org/10.1080/ 15205436.2014.891138.

Haslam, Alexander S., Penelope J. Oakes, Katherine J. Reynolds \& John C. Turner. 1999. Social identity salience and the emergence of stereotype consensus. Personality and Social Psychology Bulletin 25 (7). 809-818.

Haugh, Michael. 2010. Jocular mockery, (dis)affiliation, and face. Journal of Pragmatics 42. 2106-2119.

Her, Minyoung. 2020. How is COVID-19 affecting South Korea? What is our current strategy? Disaster Medicine and Public Health Preparedness. https://doi.org/10.1017/dmp.2020.69

Hooley, Daniel M. 1997. Roman Satire. Malden/Oxford: Blackwell.

Jenkins, Henry, Sam Ford \& Joshua Green. 2013. Spreadable Media: Creating Value and Meaning in a Networked Culture. New York/London: New York University Press.

Jensen, Minna S., Christina Neumayer \& Luca Rossi. 2018. Brussels will land on its feet like a cat: Motivations for memefying \#Brusselslockdown. Information, Communication \& Society, 1-17. https://doi.org/10.1080/1369118x.2018.1486866.

Kaplan, Robert M. \& Gregory C. Pascoe. 1977. Humorous lectures and humorous examples: Some effects upon comprehension and retention. Journal of Educational Psychology 69. 61-65.

Kapogianni, Eleni. 2011. Irony via "surrealism". In Marta Dynel (ed.), The Pragmatics of Humour across Discourse Domains. Amsterdam: John Benjamins. 
Kayam, Orly. 2017. The readability and simplicity of Donald Trump's language. Political Studies Review 16 (1). 73-88. https://doi.org/10.1177\%2F1478929917706844.

Kearns, Kate. 2000. Implicature and language change. In Jef Verschueren, Jan-Ola Östman, Jan Blommaert \& Chris Bulcaen (eds.), Handbook of Pragmatics, 895-912. Amsterdam: John Benjamins.

Kecskes, Istvan. 2014. Intercultural Pragmatics. Oxford: Oxford University Press.

Kecskes, Istvan. 2016. A dialogic approach to pragmatics. Russian Journal of Linguistics 20 (4). 26-42.

Kennedy, George A. 1994. A New History of Classical Rhetoric. Princeton: Princeton University Press.

Kimura, Doreen. 1976. The neural basis of language qua gesture. In Haiganoosh Whitaker \& Harry A. Whitaker (eds.), Studies in Neurolinguistics, 145-156. New York: Academic Press.

Knobloch-Westerwick, Silvia \& Simon M. Lavis. 2017. Selecting serious or satirical, supporting or stirring news? Selective exposure to partisan versus mockery news online videos. Journal of Communication. https://doi.org/10.1111/jcom.12271.

Kozintsev, Alexander. 2015. War propaganda and humour: World War II German, British, and Soviet cartoons. In Kamila Baraniecka-Olszewska \& Dagnoslaw Demski (eds.), War Matters: Constructing Images of the Other (1930s to 1950s), 84-107. Paris: Editions l'Harmattan.

Krauss, Robert, Yihsiu M. Chen \& Purnima Chawla. 1996. Nonverbal behavior and nonverbal communication: What do conversational hand gestures tell us? Advances in Experimental Social Psychology 28. 389-450.

Lakoff, George. 1987. The death of dead metaphor. Metaphor and Symbolic Activity 2 (2). 143-147.

Lakoff, George. 1993. The contemporary theory of metaphor. In Andrew Ortony (ed.), Metaphor and Thought, 202-251. Cambridge: Cambridge University Press.

Lakoff, George \& Mark Johnson. 2003 /1980. Metaphors We Live By. Chicago: University of Chicago Press.

Larina, Tatiana, Vladimir I. Ozumenko \& Douglas M. Ponton. 2020. Persuasion strategies in media discourse about Russia: Linguistic ambiguity and uncertainty. Lodz Papers in Pragmatics 15 (1). 3-22.

Latta, Robert. 1999. The Basic Humor Process: A Cognitive-Shift Theory and the Case Against Incongruity. Berlin: Mouton de Gruyter.

Marín-Arrese, Juana. 2008. Cognition and culture in political cartoons. Intercultural Pragmatics 5 (1). $1-18$.

Marín-Arrese, Juana. 2015. Political cartoon discourse. In Karen Tracy, Cornelia Ilie \& Todd Sandel (eds.), The International Encyclopedia of Language and Social Interaction. https://onlinelibrary.wiley.com/browse/book/10.1002/9781118611463/title?startPage=\& alphabetRange $=\mathrm{p}$ (accessed: 1 May 2021).

Milner, Ryan M. 2013. Pop polyvocality: Internet memes, public participation, and the occupy Wall Street movement. International Journal of Communication 7 (34). 2357-2390.

Mitchell, Amy, Jeffrey Gottfried, Jocelyn Kiley \& Katarina A. Matsa. 2014. Political polarization and media habits. http://www.journalism.org/2014/10/21/politicalpolarizationmedia-habits/ (accessed: 1 May 2021).

Morreall, John. 1989. Enjoying incongruity. Humor 2 (1). https://doi.org/10.1515/humr. 1989.2.1.1.

Morreall, John. 1983. Humor and emotion. American Philosophical Quarterly 20 (3). 297-304.

Morreall, John. 2016. Philosophy of Humor. In The Stanford Encyclopedia of Philosophy. https://plato.stanford.edu/archives/win2016/entries/humor/ (accessed: 29 July 2021). 
Peniston-Bird, Corinna \& Penny Summerfield. 2001. 'Hey, you're dead!': The multiple uses of humour in representations of British national defence in the Second World War. Journal of European Studies 31. 413-435.

Plevriti, Vasiliki. 2013. Satirical user-generated memes as an effective source of political criticism, extending debate and enhancing civic engagement. https://pdfs.semanticscholar.org/d0d9/474318b12c8ef519951f1ee93b27a655092b.pdf (accessed: 31 September 2020).

Randolph, Haley E. \& Luis B. Barreiro. 2020. Herd immunity: Understanding COVID-19. Immunity 52 (5). 737-741.

Rappaport, Kim L. 1998. In the wake of Reno v. ACLU: The continued struggle in Western constitutional democracies with internet censorship and freedom of speech online. American University International Law Review 13 (3). 765-814.

Ritchie, Graeme. 2003. The Linguistic Analysis of Jokes. London: Routledge

Rocklöv, Joacim (in press). COVID-19 healthcare demand and mortality in Sweden in response to non-pharmaceutical (NPIs) mitigation and suppression scenarios. https://doi.org/ 10.1101/2020.03.20.20039594.

Rosen, Ralph. 2007. Making Mockery: The Poetics of Ancient Satire. Oxford: Oxford University Press.

Sangsuvan, Kitsuron. 2013. Balancing freedom of speech on the internet under international law. North Carolina Journal of International Law and Commercial Regulation 39. 701-732.

Schopenhauer, Arthur. 1818/1844 [1907], The World as Will and Idea (Die Welt als Wille und Vorstellung). Routledge \& Kegan Paul.

Sclafani, Jennifer. 2017. Talking Donald Trump: A Sociolinguistic Study of Style, Metadiscourse, and Political Identity. London/New York: Routledge.

Shifman, Limor. 2014. Memes in Digital Culture. Cambridge, Mass.: MIT Press.

Simpson, Paul. 1998. Odd talk: studying discourses of incongruity. In Jonathan Culpeper, Mick Short \& Peter Verdonk (eds.), Exploring the Language of Drama: From Text to Context, 34-53. London: Routledge.

Simpson, Paul. 2009. Humor: Stylistic approaches. In Jacob Mey (ed.), The Concise Encyclopedia of Pragmatics, 337-339. Amsterdam: Elsevier.

Street, John. 2001. It's just for fun: Politics and entertainment. In John Street (ed.), Mass Media, Politics and Democracy, 60-80. London: Palgrave.

van Leeuwen, Theo. 2008. Discourse and Practice: New Tools for Critical Discourse Analysis. Oxford: Oxford University Press.

van Zoonen, Liesbet. 2005. Entertaining the Citizen: When Politics and Popular Culture Converge. Lanham: Rowman and Littlefield.

Winter, Eugene. 1994. Clause relations as information structure: Two basic text structures in English. In Malcolm Coulthard (ed.), Advances in Written Text Analysis, 46-68. London: Routledge.

Young, Malcolm. 1995. Black humour: making light of death. Policing and Society (5) 2. 151-167. Young, Dannagal G. 2013. Entertainment, satire, and the big questions of our political world. In Robert W. Glover \& Daniel Tagliarina (eds.), Teaching Politics beyond the Book: Film, Texts, and New Media in the Classroom, 179-198. New York: Bloomsbury.

Ziv, Avner. 1988. Teaching and learning with humor: Experiment and replication. Journal of Experimental Education 6 (1). 37-44.

\section{Article history:}

Received: 29 February 2021

Accepted: 28 June 2021 


\section{История статьи:}

Дата поступления в редакцию: 28 февраля 2021

Дата принятия к печати: 28 июня 2021

\section{Bionote:}

Douglas Mark PONTON is Associate Professor of English Language and Translation at the Department of Political and Social Sciences, University of Catania. His research interests include political discourse analysis, ecolinguistics, sociolinguistics, applied linguistics, pragmatics and critical discourse studies. Recent publications include For Arguments Sake: Speaker Evaluation in Modern PoliticalDiscourse and Understanding Political Persuasion: Linguistic and Rhetorical Aspects. As well as politics, his research deals with a variety of social topics including tourism, the discourse of mediation, ecology, local dialect and folk traditions, including proverbs and the Blues.

\section{Contact information:}

University of Catania

Via Vittorio Emanuele II 49, Catania, 95131, Italy

e-mail:dmponton@gmail.com

ORCID: 0000-0002-9968-1162

\section{Сведения об авторе:}

Дуглас Марк ПОНТОН - доктор, профессор, преподаватель английского языка и перевода на кафедре политических и социальных наук в Катанийском университете (Италия). Сфера его научных интересов включает анализ политического дискурса, эколингвистику, социолингвистику, прикладную лингвистику, прагматику и критический дискурс-анализ. Его последние публикации: For Arguments Sake: Speaker Evaluation in Modern Political Discourse («Во имя аргументов: оценка оратора в современном политическом дискурсе») и Understanding Political Persuasion: Linguistic and Rhetorical Aspects («Способы убеждения в политике: лингвистические и риторические аспекты»). Наряду с политикой интересы Д.М. Понтона связаны с социальной тематикой: туризмом, дискурсом медиации, экологией, местными диалектами, народными традициями, пословицами и блюзом.

\section{Контактная информация:}

University of Catania

Via Vittorio Emanuele II 49 Catania, 95131, Italy

e-mail:dmponton@gmail.com

ORCID: 0000-0002-9968-1162 